\title{
O DIREITO AO JUIZ NATURAL E O MEDIADOR
}

\section{THE RIGHT TO THE NATURAL JUDGE AND THE MEDIATOR}

\author{
Sandra Regina Martini ${ }^{1}$ \\ João Paulo K. Forster ${ }^{2}$ \\ Ana Luísa Michelon ${ }^{3}$
}

\section{RESUMO}

A partir de casos da Corte Interamericana de Direitos Humanos (CIDH) e da Corte Europeia de Direitos Humanos (CEDH), o presente trabalho traz uma reflexão acerca do princípio da imparcialidade na figura do juiz natural e do mediador. Como princípio concretizador da segurança jurídica, deve ser garantido ao cidadão ser julgado por um juiz constitucionalmente competente, imparcial, constituído in abstrato por lei para o pleno desempenho da função jurisdicional, e por um mediador igualmente imparcial, facilitador do diálogo entre as partes no processo de mediação. O objetivo é compreender as implicações de discussões que se vêm construindo em torno das intersecções do princípio da imparcialidade na prática da mediação e nas práticas judiciais.

Palavras-chave: Juiz natural. Imparcialidade. Neutralidade. Mediação. Cortes Internacionais.

\begin{abstract}
Based on cases of the Inter-American Court of Human Rights (IACHR) and the European Court of Human Rights (ECHR), this paper examines the natural judge and relates him to the mediador. As a concrete principle of legal certainty, the citizen must be guaranteed judgement by a constitutionally competent, impartial judge, constituted in abstract by law for the full performance of the judicial function, and by an equally impartial mediator, facilitator of the
\end{abstract}

\footnotetext{
1 Professora Produtividade CNPq, Pós-doutora em Direito pela Università de Roma Tre, Pós-doutora em Política Pública pela Università do Salento. Professora e Coordenadora do Mestrado em Direitos Humanos da UniRitter e Professora Visitante no PPGDIR/UFRGS e na UFMS. E-mail: srmartini@terra.com.br

${ }^{2}$ Mestre e Doutor em Direito pela URGS. Professor da Graduação e do Programa em Pós-Graduação Stricto Sensu (Mestrado) em Direitos Humanos do Centro Universitário Ritter dos Reis - Laureate Internacional Universities - UniRitter. Advogado. E-mail: joão_forster@uniritter.edu.br

3 Mestranda em Direitos Humanos na UniRitter - Laureate Internacional Universities. Bolsista CAPES. Especialização em Direito Público pela Fundação Escola Superior do Ministério Público - RS, FESMP/RS, Brasil. E-mail: anamichelon@hotmail.com
} 
dialogue between the parties in mediation. The objective is to understand the implications of discussions that have been built around the intersections of the principle of impartiality in the practice of mediation and judicial practices.

Keywords: Natural judge. Impartiality. Neutrality. Mediation. International Courts.

\section{Introdução}

Este estudo pretende analisar como o juiz natural e o mediador concretizam o princípio da imparcialidade por meio da jurisprudência nacional e da jurisprudência das Cortes internacionais. Assim, jurisprudência da CIDH e a da CEDH, da qual o Estado brasileiro é aderente, serão indicadas paralelamente à apresentação dos desdobramentos teóricos, com a citação de casos em que os conceitos imparcialidade e neutralidade em análise foram aplicados.

A imparcialidade é uma garantia fundamental cuja concretização depende exclusivamente dos humanos que o operacionalizam no processo. Exige-se que o julgador se abstenha de atuar no processo caso verifique a impossibilidade de promover o devido processo legal. De outro lado, ao mediador se impõe, não possuir nenhum interesse próprio sobre o objeto da demanda, além garantir o equilíbrio de poder entre as partes. Também não pode defender ou representar nenhum dos mediados, sob pena de violação da garantia.

A partir das análises de julgados internacionais - Barreto Leiva vs. Venezuela e Piersack vs. Bélgica -, foi analisado o princípio da imparcialidade no contexto do juiz natural, na sua efetividade e na sua correlação com o processo de mediação. Como considerar o princípio do juiz natural na realidade atual, em que tudo vem se transformando? $\mathrm{O}$ juiz natural, assim como a Justiça, deve estar adaptado às circunstâncias do caso concreto, preservando aos cidadãos a democracia e fazendo evoluir a jurisprudência e trazendo outras formas para resolução de conflito.

A eficiência e a ineficiência dos julgados e medidas alternativas para a concretização desse direito humano processual serão examinadas a fim de elaborar reflexões necessárias para melhor compreensão do papel do juiz natural. Para a pesquisa foi utilizada a técnica bibliográfica em complemento à metodologia dedutiva

\section{O juiz natural a partir de julgados da CIDH e da CEDH}

Alguns acordos internacionais que versam sobre direitos humanos, como os realizados pelas CIDH e CEDH, são responsáveis pela incorporação de garantias humanas ao nosso ordenamento jurídico brasileiro. Percebe-se que, nessas duas Cortes, uma das mais 
relevantes garantias individuais no processo é a do direito ao juiz natural (“juiz ou tribunal competente, independente e imparcial, estabelecido anteriormente por lei”). Essa garantia, que consta em três incisos do artigo $5^{\circ}$ da Constituição - o XXXVII ("não haverá juízo ou tribunal de exceção”), o XXXV (“a lei não excluirá da apreciação do Poder Judiciário lesão ou ameaça a direito"); e o LIII ("ninguém será processado nem sentenciado senão pela autoridade") -, assegura a imparcialidade do julgador, elevando o princípio a um verdadeiro pressuposto de existência do processo. "Sem ele, a própria relação processual não pode nascer, é apenas aparente, é um não processo" (GRINOVER; GOMES; FERNANDES, 2011, p. 42).

O juiz natural é condição para o exercício da jurisdição; a ele é constitucionalmente atribuído o dever de prestar tutela jurisdicional e conduzir o processo de forma justa. Coutinho defende que o princípio da imparcialidade pode ser concebido como:

\begin{abstract}
Cada caso penal deve ser apreciado e julgado por um único órgão jurisdicional, ainda que muitos possam, eventualmente, intervir no processo, em momentos diferenciados. Faz-se, então, uma relação absoluta entre ato processual e órgão jurisdicional, de modo a que tão-só um entre tantos seja o competente para o ato. Trata-se, portanto, de identificar o órgão jurisdicional competente, matéria hoje com foro constitucional, conforme art. 5 , LIII, ou seja, "ninguém será processado nem sentenciado senão pela autoridade competente". O princípio do Juiz Natural, como se sabe, vem complementado, de perto, pela regra do inciso XXXVIII , isto é, "não haverá juízo ou tribunal de exceção". Por evidente, as regras refletem, até pela sua topografia, garantia fundamental do cidadão (COUTINHO, 2008, p. 168).
\end{abstract}

Os princípios processuais estão calcados nos princípios constitucionais, porque deles é que provém sua validade. E, ainda que se possa cogitar o fundamento de base no direito natural e que o homem precede a lei, é a partir da criação da Constituição que as garantias fundamentais são reconhecidas, e sua proteção se torna inerente a todas as normas inferiores (THUMS, 2006).

Uma das principais razões do princípio do juiz natural é garantir a imparcialidade do julgador. Tendo em vista que não se pode aplicar o direito ao caso em concreto sem que o aludido órgão julgador seja imparcial, esse princípio é considerado como uma importante característica da jurisdição e imprescindível ao Estado de Direito. No entender do Min. Celso de Mello, no HC 81.963:

o postulado do juiz natural, em sua projeção político-jurídica, reveste-se de dupla função instrumental, pois, enquanto garantia indisponível, tem por titular, qualquer pessoa exposto, em juízo criminal, à ação persecutória do Estado, e, enquanto limitação insuperável, representa fator de restrição que incide sobre órgãos do poder estatal incumbidos de promover, judicialmente, a repressão criminal [...]. (GIACOMOLLI, 2014, p.265). 


\title{
2.1 Caso Barreto Leiva vs. Venezuela
}

O artigo 8.1 da Corte Interamericana de Direitos Humanos garante o direito ao cidadão de ser julgado por "um tribunal competente [...] estabelecido anteriormente por lei". Tal disposição se relaciona com o conceito de juiz natural, uma das garantias do devido processo, reconhecida por determinado setor da doutrina como seu pressuposto. E assegura às pessoas o direito de serem julgadas, em geral, por tribunais ordinários, em conformidade com procedimentos legalmente estabelecidos $(\mathrm{CADH}$, art. 75, p.15). O postulado do juiz natural representa garantia constitucional indisponível, assegurada a qualquer réu; nesse sentido, importa observar a sustentação da Corte Interamericana no caso Barreto Leiva vs. Venezuela:

\begin{abstract}
Oscar Enrique Barreto Leiva (doravante denominado "o senhor Barreto Leiva" ou "a suposta vítima") foi condenado a um ano e dois meses de prisão por crimes contra o patrimônio público, como consequência de sua gestão, no ano de 1989, como Diretor Geral Setorial de Administração e Serviços do Ministério da Secretaria da Presidência da República. Segundo a Comissão, no trâmite de um processo penal perante a Corte Suprema de Justiça contra o então Presidente da República, um senador e um deputado, o senhor Barreto foi intimado a declarar como testemunha e, posteriormente, foi expedido mandado de detenção contra ele. A Comissão argumentou que neste processo não se notificou de maneira prévia a suposta vítima dos crimes de que era acusado em razão do caráter secreto da etapa de inquérito. Além disso, a Comissão argumentou que o segredo da etapa de inquérito fez com que o senhor Barreto Leiva não tenha sido assistido por um defensor de sua escolha nessa etapa do processo, e não tenha interrogado as testemunhas, conhecido as provas que estavam sendo reunidas, apresentado provas em sua defesa e controvertido o acervo probatório contra ele. Além disso, segundo a Comissão, o fato de a Corte Suprema de Justiça ter sido o tribunal que conheceu e sentenciou em única instância o caso da suposta vítima constituiria uma violação de seu direito a ser julgada por um tribunal competente, em razão de que não contava com um foro penal especial, bem como uma violação de seu direito a recorrer da sentença condenatória. Finalmente, a Comissão considerou que foi imposta ao senhor Barreto Leiva uma prisão preventiva com fundamento exclusivo em indícios de culpabilidade, sem a possibilidade de obter a liberdade sob fiança, e que durou mais tempo do que a condenação finalmente recebida.
\end{abstract}

É possível depreender que, segundo a jurisprudência da Corte, pelo princípio do juiz natural somente a lei pode indicar previamente qual tribunal irá julgar o réu. Nos casos de conexão, deveria existir uma regra prévia que excetue o julgamento por juiz diverso; porém, a Corte reconhece que o tribunal pode ser responsável pelo julgamento originário, não violando o princípio do juiz natural, conforme trecho da sentença proferida:

foro não necessariamente entra em colisão com o direito ao juiz natural, se aquele se encontra expressamente estabelecido e definido pelo Poder Legislativo e atende a uma finalidade legítima, como antes se afirmou. Desta forma, não apenas se respeita o direito em questão, mas o juiz se converte no juiz natural do acusado. Se, ao contrário, a lei não consagra o foro e este é estabelecido pelo Executivo ou pelo próprio Poder Judiciário, afastando assim o indivíduo do tribunal que a lei consagra como seu juiz natural, ver-se-ia violado o direito a ser julgado por um juiz 
competente. Do mesmo modo, se a conexão está expressamente regulamentada na lei, o juiz natural de uma pessoa será aquele a quem a lei atribua competência nas causas conexas. Se a conexidade não está regulamentada pela lei, seria violatório afastar o indivíduo do juiz originalmente chamado a conhecer do caso (art. 77, $\mathrm{CADH})$.

No caso em tela, houve uma realocação dos "poderes de derretimento da modernidade", como assegura Bauman (2001, p.13). As práticas processuais às vezes se autodeterminam o poder de julgar, gerando interpretações que adéquam às normas, mas ao interessado de certa forma altera o andamento do devido processo legal e reduz a possibilidade de defesa, gerando insegurança, que não pode ser evitada, porque na verdade o juiz imposto pela regra da conexão não é o juiz natural.

\subsection{Caso Piersack vs. Bélgica,}

No caso Piersack vs. Bélgica, o Tribunal Europeu de Direitos Humanos afirmou que todo juiz em relação ao qual possa haver razões legítimas para duvidar de sua imparcialidade deve abster-se de julgar o processo. O que está em jogo é a confiança que os tribunais devem inspirar nos cidadãos em uma sociedade democrática. No julgamento proferido pela Corte, houve o entendimento de que a imparcialidade do juiz não possui somente uma natureza subjetiva, vislumbrando-se também seu aspecto objetivo. A primeira estaria vinculada aos sentimentos e convicções pessoais do magistrado frente ao caso concreto. A segunda buscaria evidenciar um juiz que, na situação palpável, seja capaz de demonstrar a imparcialidade, emanando garantias que excluam dúvidas pertinentes sobre a temática. Entre os principais dispositivos que subsidiam o sistema acusatório encontram-se art. 129, inc. I, que assegura que a ação penal pública é cometida pelo Ministério Público; art. 5, inc. LIV, devido processo legal; art. 5, inc. LV, garantia do contraditório e da ampla defesa; art. 5, inc. LX, publicidade dos atos processuais. Nesse sentido, Denise Neves Abade afirma que:

[...] não resta dúvida que a Constituição da República adotou todas as elementares do princípio acusatório, na medida em que conferiu ao Ministério Público a privatividade do exercício da ação penal pública, consagrando o devido processo legal e assegurando, no mesmo passo, o julgamento dos feitos por um juiz competente e, obviamente, imparcial (ABADE, 2005, p.117).

A Constituição Federal deu exclusividade da ação penal ao Ministério Público, separando as funções dos sujeitos processuais. Há correlação íntima entre a ordem constitucional vigente e o sistema acusatório adotado que visa retirar o juiz da persecução penal, mantendo-o imparcial (RANGEL, 2007, p. 20). A imparcialidade do órgão 
jurisdicional configura princípio supremo do processo, e "funciona como uma meta a ser atingida pelo juiz no exercício da jurisdição, razão por que se busca criar mecanismos capazes de garanti-la”. (COUTINHO, 2000, p. 12).

No sistema acusatório, o modelo processual é orientado à solução da controvérsia por heterocomposição, que tem como princípio informador audiatur et altera pars, de modo a incluir o juiz na posição de um terceiro desinteressado. Assim, pretende-se alcançar um julgamento imparcial, de forma a aplicar o direito objetivo e a tutelar os direitos fundamentais dos acusados (MAYA, 2014, p. 74). É fundamental nesse sentido compreender que, "para o juiz manter uma postura de equidistância em relação às partes, exige-se dele uma posição para além dos interesses delas, permitindo uma atuação desapaixonada, na qual o juiz não favorece nenhuma das partes" (COUTINHO, 2001, p.11). Assim entendeu o Tribunal Europeu dos Direitos Humanos no julgamento do caso Piersack vs. Bélgica, ao considerar a imparcialidade do julgador como garantia constitucional a ser respeitada.

No Caso Piersack vs. Bélgica, o TEDH considerou violado o direito a um juiz imparcial por ter o magistrado em função que presidiu o Tribunal e condenou Piersack ter sido coordenador da promotoria que investigou o caso. Mesmo que indiretamente, segundo o TED, houve a superposição das funções de acusar e julgar. Segundo o Tribunal, os cidadãos 'possuem o direito de temer a inexistência de suficientes garantias de imparcialidade', bastando a dúvida acerca da imparcialidade. (GIACOMOLLI, 2014, p.243).

$\mathrm{Na}$ fundamentação desse julgado, a imparcialidade tem por função evitar a arbitrariedade e a contaminação subjetiva do julgador. Nesse sentido, o Tribunal distinguiu entre a imparcialidade objetiva e a subjetiva:

\begin{abstract}
es en torno a la «imparcialidad del Tribunal» donde se encuentra la sustancia de la sentencia, así como en su significado en el artículo 6.1 del Convenio: El Tribunal precisa, en primer lugar, el doble aspecto subjetivo y objetivo con el que debe analizarse la imparcialidad de los Tribunales. Subjetivo en cuanto a la convicción personal de un juez concreto en un caso concreto. Objetivo en cuanto a que un juez ofrezca garantías suficientes para excluir cualquier duda legítima sobre la imparcialidad de su actuación. No basta que el juez actúe imparcialmente, sino que es preciso que no exista apariencia de parcialidad; «en esta materia incluso las apariencias tienen importancia», ya que «lo que está en juego es la confianza que los Tribunales deben inspirar a los ciudadanos en una sociedad democrática ${ }^{4}$.
\end{abstract}

\footnotetext{
4 Tradução nossa: "É em torno da" imparcialidade da Corte "onde se encontra a substância da sentença, bem como seu significado no artigo 6.1 da Convenção: A Corte especifica, primeiro, o duplo aspecto subjetivo e objetivo com o qual deve analisar a imparcialidade dos tribunais. Assunto com relação à condenação pessoal de um juiz específico em um caso específico. Objetivo: um juiz oferece garantias suficientes para excluir qualquer dúvida legítima sobre a imparcialidade de sua ação. Não basta que o juiz aja com imparcialidade, mas é necessário que não aja aparência de viés; "Nesse assunto, até as aparências são importantes", pois "o que está em jogo é a confiança de que os tribunais devem inspirar os cidadãos em uma sociedade democrática”.
} 
Depreende-se que para a Corte a imparcialidade objetiva diz respeito a um juiz que ofereça garantias suficientes para que não ocorram dúvidas acerca de sua atuação, e está substanciada na relação do juiz com o caso penal. Por outro lado, a imparcialidade subjetiva está relacionada ao vínculo do juiz com as partes. Frederico Marques destaca que "para o juiz exercer função jurisdicional, é necessário, além da capacidade funcional, ter a capacidade de exercício, que pode ser genérica - que diz respeito a regular nomeação e investidura no cargo - ou específica - que pode ser considerada objetivamente ou subjetivamente" (MARQUES, 1997, p.23).

$\mathrm{Na}$ verdade, esses institutos estão regulados no Código de Processo Penal de forma equivocada, pois todas as hipóteses referentes às incompatibilidades, impedimentos e suspeições "[...] se ocupam da tutela de um único e mesmo valor positivado no ordenamento processual: a imparcialidade da jurisdição" (OLIVEIRA, 2009, p. 265).

No caso Piersack vs. Bélgica, a imparcialidade do julgador, em seu aspecto objetivo, resta prejudicada em razão de contato prévio do magistrado com questões da lide. Sobre a importância da aparência de imparcialidade, Ferrajoli leciona que:

\footnotetext{
que é essencial para a manutenção da confiança que os tribunais devem inspirar nos cidadãos. Não se pode, então, ter um juiz que atue simultaneamente como órgão de acusação e como juiz. Isso desestabiliza a credibilidade da prestação jurisdicional e vai de encontro com o modelo teórico acusatório em que a separação entre juiz e acusação é o mais importante de todos os elementos constitutivo (FERRAJOLI, 2001, p.564).
}

Isso fica claro no entendimento do Supremo Tribunal Federal. Ao julgar o HC 94.641 considerou o Ministro Cezar Peluso ter havido quebra da imparcialidade objetiva na situação fática, pois o mesmo juiz que presidiu o procedimento administrativo de averiguação de paternidade recebeu a denúncia, decretou prisão preventiva e proferiu sentença (MAYA, 2014, p. 87). Nesse caso, a imparcialidade restou prejudicada, e a neutralidade também, mesmo porque no palco da ciência é difícil o sujeito alcançar a neutralidade ao interpretar.

No Direito, o conceito de imparcialidade poderá ser compreendido com diversas modulações, algumas vezes causando insegurança jurídica e instabilidade. Segundo Orlandi, “o sentido é assim uma relação determinada do sujeito - afetado pela língua - com a história". Por essa razão, a autora afirma que "não há discurso sem sujeito e não há sujeito sem ideologia. Ideologia e inconsciente estão materialmente ligados” (ORLANDI, 1999, p. 47). Com base nessa relação, podemos questionar como o princípio da imparcialidade pode afetar a interpretação de uma lei ou dos princípios jurídicos neles materializados. 
A aplicação de normas exige um juízo de adequação ao caso concreto: como poderia o operador do Direito alcançar a adequação de um julgado sem se posicionar diante de fatos, narrativas, normas para analisá-los? De acordo com Warat, as possibilidades de atribuição de sentido advêm, em cada contexto, do jogo de sentidos acolhido pelo senso comum teórico e do sujeito individual (WARAT, 1994). Em outras palavras, para Warat, o sujeito ao interpretar assume um posicionamento com base em um determinado conjunto de valores. De posse do sentido eleito, fundamenta a argumentação, adota um ponto de vista. Nesse mesmo sentido, considera Coutinho que não é possível haver nem imparcialidade, nem neutralidade, nem perfeição na figura do juiz porque como todos os homens está sujeito a ser afetado pela história de sua sociedade e pela sua própria história. Parece, pois, que a desconexão entre o dever ser e o ser só é possível e aceita em função de fatores externos (manutenção do status quo) e internos (manutenção, ainda que vã, do equilíbrio), em uma retroalimentação do sistema processual penal em vigor (COUTINHO, 2015).

Essas considerações validam que argumentação jurídica, de caráter dinâmico e contextual, depende da antecipação de sentido que possa ser dado pelos operadores do Direito sempre adequada e motivada à luz da Constituição Federal. Como todos os outros seres humanos, o operador também é construtor da realidade e carrega consigo "experiências vividas, ideologias e valores que amoldam a sua personalidade e acabam por determinar atitudes inconscientes como a intuição sobre determinado fato" (LOPES, 2017, p. 877).

A imparcialidade não pode ser considerada apenas uma garantia do cidadão: ela define todo o processo de tomada de decisão. Não basta ser subjetivamente imparcial. É necessário que a imparcialidade seja demonstrada objetivamente pelo operador do direito, um terceiro desinteressado. Nas práticas judiciais que envolvam resoluções de conflitos, as decisões carregam a ideologia do sujeito de direito, sua alma, dor, seu amor. O que não se admite é que, em nome de uma suposta "subjetividade" ou de quaisquer valores, o juiz atue parcialmente e fora dos limites da lei e dos princípios constitucionais, tornando algumas decisões destituídas de significado por não se prestarem à decodificação de todo e qualquer público, mas sim a um próprio do operador.

\section{0 mediador na busca por um processo justo}

A origem do direito fundamental ao processo justo deita raízes em quase todas as Constituições modernas, mas também encontra lastro na previsão do artigo X da Declaração Universal dos Direitos Humanos. No Brasil, encontra seu amparo no art. 5º, LIV, da Constituição Federal, apresentando-se como "modelo mínimo de atuação processual do 
Estado e mesmo dos particulares em determinadas situações substanciais" (SARLET; MARINONI; MITIDIERO, 2012, p.616).

$\mathrm{Na}$ busca desse processo justo, o mediador também possui papel a desempenhar. Ele atua na qualidade de terceiro imparcial de modo a colaborar para que os "circuitos" se restabeleçam, e cria condições para os bons resultados da confiança que se pretende estabelecer, sobretudo porque não profere decisão acerca do conflito. Nesse sentido, Mediar, [...] quer dizer reconjugar o que agora está desconectado - porque a relação e o circuito se interromperam [...]. Mas os circuitos eram e poderão ainda ser ativos" (RESTA, 2008. p. $105)$.

Fundada na sensibilidade, a mediação conta com a figura de um mediador que auxilia as partes envolvidas a "desdramatizar seus conflitos" a fim de resgatar o que há de bom na relação. Por isso, Warat entende que o processo da mediação "não é uma técnica, nem uma filosofia ao modo tradicional; é uma forma de ver a vida que encontra o sentido na própria experiência. O autor fala da mediação como uma forma de "cultura e de viver" (WARAT, 2004, p.33).

O mediador, terceiro imparcial, estimula as partes a refletir sobre interesses e desejos, formular novas opções que lhes mostrem que também podem decidir de maneira justa visando à pacificação social. Nesse trabalho de resgate, é livre e responsável. É possível compará-lo com um maestro ou diretor de cinema:

não tomam o lugar dos atores ou dos músicos, a quem compreendem, infundem confiança, insuflam ritmo, trazem uma espécie de energia suplementar e impulsionam a dar todo seu talento. Mas, no final das contas, diretor e maestro são tidos como primeiros responsáveis pela obra produzida: solidão do catalisador" (SIX, 2001, p.223).

Sob a perspectiva da mediação, o conflito é parte integrante da vida do homem, por isso não parte da premissa que é um problema a ser resolvido/decidido a qualquer custo e de forma rápida. É uma prática ética, que permite às pessoas compreenderem-se a si mesmas e se relacionarem umas com as outras através do marco do conflito (BARUCH BUSH; FOLGER, 1996, p. 22).

O conflito provoca sofrimento, pode ser vivido como uma ameaça ou simplesmente incomodar, e na medida do possível se tenta evitá-lo. A reação de evitamento às vezes não é factível, porque as consequências do conflito podem continuar pesadamente na vida das pessoas envolvidas; outras vezes, o evitamento não é nem mesmo desejável, porque ao fazê-lo renuncia-se aos próprios direitos ou à própria dignidade. 
Sob a perspectiva do processo, o conflito não é considerado. Nas palavras do juiz Alexandre Rosa o conflito é "desqualificado e varrido para debaixo desse remédio-simulacro processo" (WARAT, 2004, p.11). Para Amilton Carvalho, o conflito deve ser julgado o mínimo possível (CARVALHO, 1997, p. 368). Sob tal percepção, o Estado-juiz deve julgar menos, no sentido de deixar as partes se manifestarem a tal ponto que o juiz tenha condições de julgar.

A mediação é um processo que estrutura a intervenção das partes, e não do Estado; que favorece sua participação e legitimação, dando-lhes espaço para que sejam autônomas, autênticas, fraternas, solidárias, que se coloquem uma no lugar das outras, e assumam a responsabilidade na resolução do conflito ${ }^{5}$. Assim, em contraposição ao modelo de Justiça comum que se instrumentaliza na imposição de soluções, temos na mediação "um terceiro imparcial que auxilia as partes a chegarem, elas próprias, a um acordo entre si, através de um processo estruturado" (GARCEZ, 2004, p.39).

A fim de permitir o reencontro no outro, surgem os seguintes problemas: "como manter a estraneidade em relação às questões, interesses e sentimentos trazidos pelos mediandos, sem interferir na decisão deles? Quais os instrumentos podem ser utilizados pelo mediador para garantir a imparcialidade, visando à busca do direito fundamental ao processo justo?” (PACHECO, 2014, p. 01)

O modelo cooperativo da mediação é diferente do modelo cooperativo do processo. O juiz avalia os argumentos trazidos pelas partes, enquanto o mediador estimula, a partir de ferramentas específicas, o entendimento entre os envolvidos para que "[...] as partes se escutem e compreendam a si mesmas e entre si, reconheçam, entendam e hierarquizem seus próprios interesses e necessidades [...]" (CALMON, 2013, p.118). A escuta do mediador empodera os envolvidos a ponto de a decisão contemplar a ideia do ganha/ganha, princípio da cooperação na mediação, prevalecendo o foco na negociação entre as partes, e não no resultado.

No entender de Warat, o mediador, na negociação, ajuda as partes a transformar o conflito, “[...] o mediador ocupa um lugar de amor, é uma figura imparcial, sem poder decisório, ajuda na reconstrução simbólica: seu discurso é amoroso, poético" (WARAT, 2004, p.18). Prossegue:

\footnotetext{
${ }^{5}$ [...] temos "de um lado o dizer o Direito próprio do Estado, que caracteriza a jurisdição como poder função estatal e, de outro, o elaborador/concertar/ pactar/ construir a resposta para o conflito em que reúne as partes. Essas ideias permitem que o direito seja construído em conjunto" (GHISLENE; SPENGLER, 2011, p. 47).
} 


\begin{abstract}
"Como se faz um mediador? Para ser mediador é preciso aprender com a própria experiência, com o mundo e com os outros (...). Qual o ofício do mediador? Fazer a psicoterapia dos vínculos conflitivos, a psicoterapia do reencontro amoroso, transformando vínculos conflitivos em vínculos amorosos (Terapia do reencontro). O que é preciso para ser mediador? Em primeiro lugar: entender de gente. Como o mediador realiza seu ofício na prática? O mediador usa a comunicação mais corporal e não-verbal. Inclusive os silêncios. É essencial trabalhar os não ditos dos sentidos. Qual a linguagem que o mediador utiliza? Utiliza uma linguagem poética, dos afetos, do coração" (WARAT, 2004, p. 29-39).
\end{abstract}

O mediador tem poderes e utiliza prerrogativas para se tornar um terceiro imparcial e neutro, pois não julga. Ele conduz o procedimento e não interfere no entendimento do ponto de vista das partes; facilita o diálogo entre os envolvidos, direcionando os pontos tratados no procedimento.

O mediador é um tradutor que deve ficar no meio das linguagens diversas, deve conhecer duas línguas e servir de trâmite, de meio entre uma e outra; importante função essa quanto mais línguas, linguagens, culturas, mundos entram em contato e têm necessidade de transformar o conflito potencial em comunicação (RESTA, 2004, p. 131).

Do ponto de vista da neutralidade, "a virtude do mediador é aquela do estar no meio, de compartilhar, e até mesmo do "sujar as mãos"' (RESTA, 2004, p.125). Resta explica a neutralidade do mediador em uma fórmula, aduzindo que,

\begin{abstract}
enquanto o juiz é pensado, nos sistemas modernos, como o nec utrum, nem um nem outro, nem isto nem aquilo, justamente neutro, o mediador deve ser isto e aquilo, deve perder a neutralidade e perde-la até o fim. Só assim se realiza a sua identidade como diferença em relação ao juiz, mas se realiza sua diferença, como identidade, em relação às partes. Enquanto as partes litigam e só veem seu próprio ponto de vista, cada uma de maneira especular em relação à outra, o mediador pode ver as diferenças comuns aos conflitantes e recomeçar daqui, atuando com o objetivo de as partes retomarem a comunicação, exatamente o munus comuns a ambas. Somente graças a esta diferença no que diz respeito ao juiz, a essa sua intrínseca parcialidade, o mediador pode encontrar o remédio para o conflito (RESTA, 2004, p. 126).
\end{abstract}

Assim, mediador é aquele que contribui para que o conflito seja percebido e analisado de forma pedagógica; deve chamar os envolvidos para a transferência de um para o outro, para que possam interpretar o conflito, elaborar as contradições a fim de compreendêlas. "O mediador [...] chama, para o lugar das transferências, o outro ou os outros envolvidos no conflito, tentando que cada um, olhando-se a partir do olhar do outro, possa transformarse, reencontrando-se em suas pulsões de vida" (WARAT, 2001, p. 86).

\title{
4 Considerações finais
}


Com a evolução social ocorrida, o princípio do juiz natural passou ser praticamente unanimidade dentro dos textos constitucionais dos Estados. A ausência dessa garantia impossibilita a própria função jurisdicional por se tratar de um verdadeiro pressuposto para a existência do processo. É nas dimensões do princípio constitucional do juiz natural que a imparcialidade e a neutralidade encontram a sua fonte primeira.

A imparcialidade do órgão julgador ou do mediador significa que deve atuar distanciado dos interesses em disputa, ser comprometido com a concretização do Estado Democrático de Direito, e limitar-se a aplicar a lei sem ter convicções ou certezas acerca dos fatos atribuídos àquele que está sendo julgado ou às partes mediadas.

Distintamente, a neutralidade é "suspensão de juízo", contemplação desinteressada, o encontro com a essência. O operador do direito se desloca de sua posição, tendo a percepção de que aqueles que se submetem às suas demandas são seres humanos como ele e como tal devem ser tratados: a única coisa que deles o diferencia é a investidura de poder. Assim, a neutralidade diante de uma situação de conflito pode se afirmar impossível de ser atingida em toda a sua extensão. Exigir a neutralidade do operador do direito equivale, pois, a pedir-lhe que elimine as suas próprias crenças, e valores humanos, a sua própria essência.

No judiciário, os princípios da neutralidade e da imparcialidade têm uma ímpar e extrema largueza: são pressupostos de validade do processo, garantia de justiça para as partes e obediência ao Estado Democrático de Direito. Dois casos emblemáticos foram analisados, posicionando a Corte pela violação do direito ao duplo grau de jurisdição no caso Barreto Leiva vs. Venezuela, e pela perda indeclinável da imparcialidade dos juízes no caso Piersack vs. Bélgica, pois haviam atuado na fase de investigação, estando, assim, impedidos de participar da fase de julgamento. Cumpre ressaltar que tais postulados ganham especial relevo como mecanismo complementar de solução de disputas, consubstanciando-se em verdadeiros princípios a nortear a atuação do operador do direito.

Remete-se ao conto "A terceira margem do rio", da autoria de Guimarães Rosa (1994), de cuja natureza retórica é possível retirar uma interpretação que me parece frutífera para fazer confluir as imagens suscitadas com a representatividade do instituto da mediação, e a partir desta confluência sintetizar o objetivo do estudo.

Em linhas gerais, o conto trata de um pai que decide certo dia ir-se em uma canoa para o meio do rio, próximo à casa da família. O tempo trans-corre com o rio, e o pai ali permanece, sem jamais aportar em nenhuma das margens. De um dos filhos, o abençoado, recebe parcos alimentos ao longo dos anos e das margens. 
Um entrelaçamento simbólico pode ser feito entre a travessia de "A terceira margem do rio", e o terceiro caminho proposto na mediação, que não exclui mas participa dos dois caminhos usualmente apresentados como mutuamente excludentes pelo pensamento binário.

As margens que constrangem o curso do rio constituem uma bela metáfora das partes em conflito. As cheias e o rompimento do curso normal, com o transbordamento violento das águas por sobre as margens, é sempre uma possibilidade de um encontro com a terceira margem. Entre as margens, o tempo e a duração, entre as histórias passadas e as projeções, há sempre um caminho que participa de ambos os lados e que segue entre eles, ora sinuoso, ora mais linear, ora veloz, ora mais lento, ora avançando para a margem da direita, ora para a da esquerda. Que esse vaivém permanente entre as margens, esse movimento das águas do rio que alude ao que é vivo, ativo, pulsante, tal como nos ensina o conto de Rosa, possa representar trabalho de elaboração, de reconfiguração, que seja sustentado, de modo a que algo bom possa surgir disso.

Desse vaivém entre as margens justamente se fala da noção de "terceiro" e de um "Diritto Vivente", conforme Eligio Resta. Que os mediadores continuem desafiando para que "os que sonharam com um mundo melhor e morreram na resistência, passaram para o outro lado, ou renunciaram às suas esperanças" (WARAT, 2004, p. 193). Atravessar a margem para ver e ouvir o outro talvez seja o principal passo para a humanização tão necessária à almejada Justiça e ampliação dos espaços democráticos.

\section{Referências}

ABADE, Denise Neves. Garantias do processo penal acusatório: o novo papel do ministério público no processo penal de partes. Rio de Janeiro: Renovar, 2005.

ALVES, Murilo Cavalcanti. Dentro e fora da terceira margem: na margem do silêncio. Revista Terceira Margem, v.23, n.39, 2019.

BARUCH BUSH, R. A.; FOLGER, J. P. La promesa de mediación. Barcelona: Granica, 1996.

BAUMAN, Zygmunt. Modernidade líquida. Rio de Janeiro: Zahar, 2001.

CALMON, Petronio. Fundamentos da mediação e da conciliação. 2. ed. Brasília: Gazeta Jurídica, 2013. 
CARVALHO, Amilton Bueno de. Papel dos juízes da democracia. AJURIS: Revista da Ajuris, Porto Alegre, v. 24, n. 70, p. 345-373, jul. 1997.

CORTE EUROPEIA DE DIREITOS HUMANOS (CEDH). Case of Piersack V. Belgium, out. 1984, § 30,a. Disponível em: http://hudoc.echr.coe.int/spa?i=001-165173. Acesso em: 17 nov. 2019.

CORTE INTERAMERICANA DE DIREITOS HUMANOS (CADH). Case Barreto Leiva vs. Venezuela. 2009. Disponível em: https://www.cnj.jus.br/wpcontent/uploads/2016/04/5523cf3ae7f45bc966b18b150e1378d8.pdf. Acesso em 15 nov. 2019. COUTINHO, Jacinto Nelson de Miranda. Introdução aos princípios do Direito Processual Penal brasileiro. In: Separata ITEC, ano 1, nº 4, jan/fev/mar 2000. Disponível em: http://www.direitofranca.br/download/IntroducaoaosPrincipiosGeraisdoDireitoProcessualPen alBrasileiro2005.doc. Acesso em: 21 abril 2020.

COUTINHO, Jacinto Nelson de Miranda. O papel do novo juiz no Processo Penal. In: COUTINHO, Jacinto Nelson de Miranda (coord). Crítica à teoria geral do direito processual penal. Rio de janeiro: Renovar, 2001.

COUTINHO, Jacinto Nelson de Miranda. O princípio do juiz natural na CF/88 Ordem e desordem. Revista de Informação Legislativa, Brasília a. 45 n. 179, p. 165-178, jul./set. 2008. Disponível: https://www2.senado.leg.br/bdsf/bitstream/handle/id/176542/000843877.pdf?sequenc. Acesso em 21 abril 2020.

COUTINHO, Jacinto Nelson de Miranda. O papel do novo juiz no processo penal. Empório do Direito, 2015. Disponível em: https://emporiododireito.com.br/leitura/o-papel-do-novojuiz-no-processo-penal. Acesso em 15 nov. 2019.

GARCEZ, José Maria Rossani. Negociação. ADRS. Mediação. Conciliação e Arbitragem. Rio de Janeiro: Lumen Iuris, 2004.

GHISLENI, Ana Carolina; SPENGLER, Fabiana Marion. Mediação de conflitos a partir do Direito Frateno [recurso eletrônico]. Santa Cruz do Sul: EDUNISC, 2011. 
GIACOMOLLI, Nereu José. O devido processo penal: abordagem conforme a Constituição Federal e o Pacto de São José da Costa Rica. $3^{\text {a }}$ ed. Rev. atual. e ampl. São Paulo: Atlas, 2014. GRINOVER, Ada Pellegrini; GOMES, Antonio Magalhães Filho; FERNANDES, Antônio Scarance. As nulidades no processo penal. 12 ed. Ver. e atua. São Paulo: Revista dos Tribunais, 2011.

LOPES JÚNIOR, Aury. Direito processual penal. 14. ed. São Paulo: Saraiva, 2017.

LUIGI, Ferrajoli. Derecho y razón: teoria del garantismo penal. 5.ed. Madrid: Trotta, 2001.

MARQUES, José Frederico. Elementos de direito processual penal. Campinas: Bookseller, 1997. v. 2.

MAYA, André Machado. Imparcialidade e processo penal - da prevenção da competência ao juiz de garantias. $2^{\mathrm{a}}$ ed. rev. e ampl. São Paulo: Atlas, 2014.

OLIVEIRA, Eugênio Pacelli de. Curso de processo penal. 11 ed. Rio de Janeiro: Lumen Juris, 2009.

ORLANDI, Eni. Análise do discurso: princípios e procedimentos. Campinas; São Paulo: Pontes, 1999.

PACHECO, Caroline Oliveira. A imparcialidade como aspecto essencial ao ofício do mediador: um mecanismo para a busca do processo justo In: SEMANA DE EXTENSÃO, PESQUISA E PÓS-GRADUAÇÃO DO UNIRITTER - SEPESQ, 10, 2014, Porto Alegre. Anais [...] Porto Alegre: Centro Universitário Ritter dos Reis - UNIRITTER, 2014. Disponível em: https://www.uniritter.edu.br/files/sepesq/arquivos_trabalhos_2017/4368/1443/1764.pdf. Acesso em 15 nov. 2019.

RANGEL, Paulo. Direito processual penal. 12 ed. Rio de Janeiro: Lumen Juris, 2007. RESTA, Elígio. O Direito fraterno. Santa Cruz do Sul: EDUNISC, 2004. RESTA, Elígio. O Diritto vivente. Bari: Laterza, 2008. ROSA, João Guimarães. A terceira margem do rio. In: Ficção completa: volume II. Rio de Janeiro: Nova Aguilar, 1994, p. 409-413. Disponível em: 
https://www.aedi.ufpa.br/parfor/letras/images/documentos/ativ-a-dist-janfev2014/CASTANHAL/castanhal-2010-010/guimaraes\%20rosa\%20-

\%20a_terceira_margem_do_rio-3.pdf. Acesso em 15 nov. 2019.

SARLET, Ingo Wolfgang; MARINONI, Luiz Guilherme; MITIDIERO, Daniel. Curso de Direito Constitucional. São Paulo: RT, 2012.

SIX, Jean-François. Código da Mediação. In: Dinâmica da mediação. Belo Horizonte: Del Rey, 2001.

THUMS, Gilberto. Sistemas processuais penais. Rio de Janeiro: Editora Lumen Juris, 2006.

WARAT, Luis Alberto. Introdução Geral ao Direito. Porto Alegre: Sérgio Fabris, 1994.

WARAT, Luis Alberto. O Ofício do Mediador. Florianópolis: Habitus, 2001.

WARAT, Luis Alberto. Surfando na pororoca: ofício do mediador. Florianopólis: Fundação Boiteux, 2004. 